\title{
GPS を用いた航空管制用レーダの較正のための飛行実験
}

\author{
長岡 栄* ·天井 治* \\ Flight Experiments for Calibrating a Radar \\ Used for Air Traffic Control Using GPS \\ Sakae NAGAOKA and Osamu AMAI
}

\begin{abstract}
This paper describes the method and the results of flight experiments carried out for calibrating a radar used for air traffic control by using GPS. Two GPS sensors, i.e., one equipped on an aircraft and another installed at the control tower of Kushiro airport, were used for the experiments. Offline DGPS data processing was carried out for improving the positioning accuracy. The tracks of the aircraft were observed by the radar and by the airborne GPS sensor. Two tracks were compared with each other in order to estimate the biases in the range and azimuth measurement systems of the radar. The biases were estimated on the basis of the least squares method. Reconstructed radar tracks based on the estimated biases were in good agreement with those of DGPS/ GPS after compensating the biases.
\end{abstract}

\section{1. まえがき}

航空管制の研究では、しばしば、航空機の航跡の観測が必要となる。これには、航空路監視レーダ( Air Route Surveillance Radar：ARSR)などの航空管制用レーダで得た情報が利用される。通常利用す る情報はディジタル・データで、測角系が 0.088 度、測距系は $1 / 8 \mathrm{NM}$ を最小単位 (Least Significant Bit：LSB) として量子化されている。二次監視レーダ (SSR) の総合表示確度の要件は角度系が士0.5 度、 距離系が士0.2NM であるため、これらの測定系はLSB 程度の精度で正しく設定されていれば運用には問 題ない。

しかし、航法精度の調查等(1)では、最大覆域近傍における航跡をできるだけ正確に観測することが望ま れる。こうした場合、LSB 程度のバイアス誤差も十分問題となるため、バイアス誤差を極力小さくする 必要がある。このため、何等かの方法によりバイアス誤差を較正することが必要となる。この方法として は、地上の固定目標を用いる方法があるが、影像の大きさによる不確定性の存在や、必ずし屯適当な目標 が存在しないなどの難点がある。

近年、全世界測位システム (GPS)(2) の受信機が手軽に利用可能となり、様々な応用が試みられている。 航空管制用レーダの較正にも使用できると思われるが、これまで GPS を用いた報告例はみられない。そ こで、筆者らはGPS センサを搭載した航空機によるARSR のバイアス誤差の較正実験を試み良好な結果 を得たので報告する。

本論文では、まずARSR の誤差要因、実験の方法について概説し、ついで、バイアス誤差を補正する ための解析方法について述べる。最後にディファレンシャル GPS (DGPS) を含めたデー夕を用いた解析 結果について報告する。

*正会員 運輸省 電子航法研究所 (T181 東京都三鷹市新川 6-38-1) 


\section{ARSR の誤差要因}

ここでは較正対象とする航空路監視レーダ( ARSR) の誤差要因とそのデータの抽出方法につい て概説する。

\subsection{ARSR システムの概要}

ARSR は航空路を飛行する航空機の監視を目的と するレーダで、航空路レーダ情報処理 (Radar Data Processing : RDP) システムの重要なセンサである。 ARSR には一次監視レーダ (PSR) と二次監視レー ダ (SSR) が併設されている。表 1 に釧路 ARSR の 諸元を示す。

これらのレーダからは航空機の位置データ(距離 $r$, 方位角 $\theta$, 高度 $h)$ が得られる。距離はPSR で は航空機までの電波の往復時間、SSR では質問の 送信から応答信号の受信までの時刻から求める。高 度はSSR のモードCにより得られる航空機の気圧 高度計の情報に基づいている。

角度情報は、磁北を基準とし、360 度を 4096 に分 割 $\left(\mathrm{LSB}=0.088^{\circ}\right)$ した角度信号から成る。これは、 アンテナに取り付けたシャフトエンコーダにより、 そして基準信号はアンテナ回転軸に取り付けたマグ

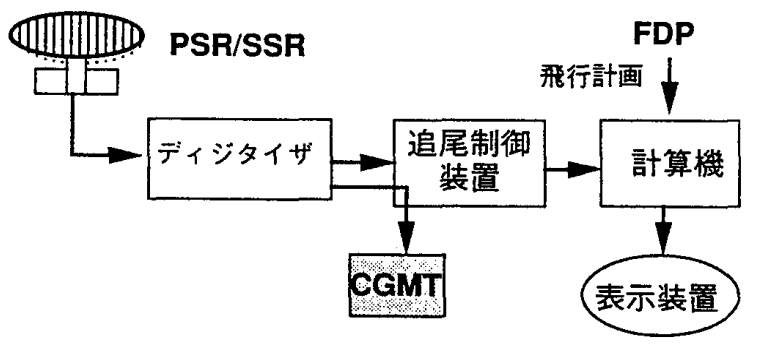

図 1 レーダシステム構成とデータ抽出部分

表 1 釧路 ARSR の諸元

\begin{tabular}{c|lc}
\hline 項 目 & PSR & S S R \\
\hline 空中線 & センタ一型複合給事方式 \\
空中線回転数 & \multicolumn{2}{|c}{$6.18 \mathrm{rpm}$} \\
最大覆域 & \multicolumn{2}{|c}{$200 \mathrm{NM}$} \\
水平ビ一ム愊 & 1.4 度以下 & $2 \pm 0.5$ 度 \\
周波数 (送信) & $1320 \mathrm{MHz}$ & $1030 \mathrm{MHz}$ \\
(受信) & $1320 \mathrm{MHz}$ & $1090 \mathrm{MHz}$ \\
送信尖頭電力 & $2 \mathrm{MW}$ & $1.5 \mathrm{~kW}$ \\
送信綝り返し周波数 & 的346 pps & 䄪346 pps \\
\hline
\end{tabular}
ネットスイッチにより発生させている。距離は LSB が 0.125NM のディジタル信号に変換されている。

これらの信号はディジタイザで相関処理や目標の方位角を推定するスライディング・ウインドウ処理な どを施される。このあと、航空機の航跡の追尾などの種々の処理が行われる。

較正対象である ARSR のデータは、図 1 のように、ディジタイザの出力をカートリッジ磁気テープ( CGMT) に記録したあのを用いた。なお、ここでは、距離はSSR の情報を用い、角度データは PSR デー タがある場合はPSR を優先し、それ以外は SSR のデータを用いている。

\section{2 誤差の要因}

ARSR の測角系，測距系の誤差要因としては下記のものが考えられる。

1) 装置の設定 (較正) 誤差 (距離系の補正値, 磁北の設定など)

2) 信号処理による推定誤差 (スライディング・ウインドウなど)

3) マルチパス等による信号の (欠落などの) 劣化

4) 雑音 (ジッター等) による誤差

ここで、1) はバイアス誤差で、2)，3) は場合によりバイアス誤差となりうる。4) はランダム誤差である。 なお、SSR の距離系についてはトランスポンダの応答信号の遅延 (ICAO の規格 ${ }^{(3)}$ は $3 \pm 0.5 \mu \mathrm{s}$ ) がバイ アスとして、ジッター成分がランダム誤差として影響する。

通常、ARSR は運用に先立ち、種々の試験を行いバイアス誤差を極力軽減するように設定してある。 PSR の精度要件は測角系で 0.2 度、測距系で $1 / 6 \mathrm{NM}$ または実距離の $5 \%$ のいずれか大きい方となってい る。

測角系の較正は日昇時の太陽ノイズによる影像や地上の固定目標などの影像を頼りに行うが、確度が 0.5 度程度といわれている。距離系については、これまで、山や島など固定目標によらざるを得なかった。 


\section{3. 実験の方法}

\section{1 実験用航空機と飛行経路}

GPS センサ（パイオニア AVIC-G10）を搭載した実験機（ビーチクラフトB99）を釧路空港 $\rightarrow$ 紋別 $\rightarrow$ 札幌 $\rightarrow$ 紋別 $\rightarrow$ 釗路のコースで飛行させた。これを釧路 ARSRにより約 10 秒毎に観測した。この航跡と GPS で約 1 秒毎に取得した航跡とを比較し、4 章の計算を行う。できるだけ既存の航空路の中心線上を、高度 変更の場合を除き水平飛行させた。

図 2 に実験機の概観図を示す。マイクロストリップ・アンテナが機体ほぼ中央部に設置されている。図 3 には飛行コースと高度などを示す。

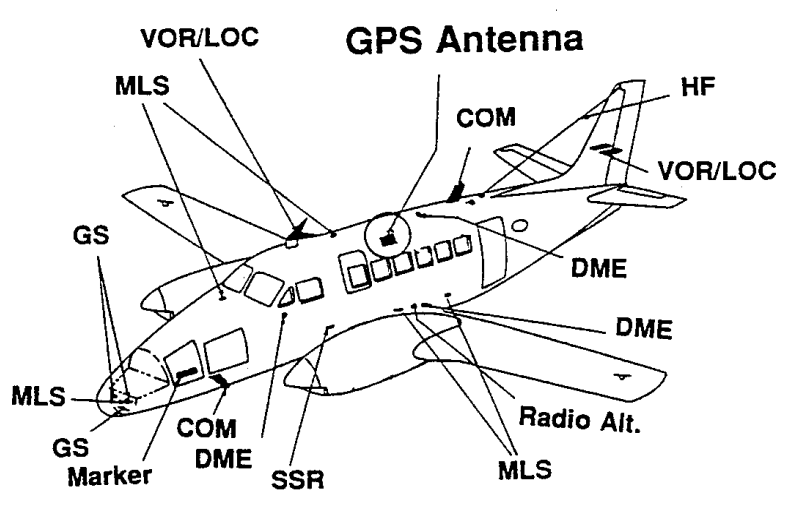

図 2 実験用航空機 (B99) とアンテナ位置

\subsection{GPS 受信機とデータ収集}

GPS の測位精度はSA (Selective Availability) のため、2 $\mathrm{drms}$ 值で $100 \mathrm{~m}$ 程度とされている。し かし、ディファレンシャル GPS (DGPS) 処理を 行うとダイナミックな利用で $5 \sim 20 \mathrm{~m}$ 程度の精 度(4)(5) が期待できる。

そこで、本実験では、DGPSにより測位精度を 向上させるため、既知地点 (釧路空港) に機上之 同一規格のセンサ (パイオニア GPS-303PT) を設 置し、当該時間の GPS デー夕を併せて取得した。 GPS-303PT は 6 チャンネルで最大 12 個の衛星を 追尾する。主な性能を表 2 に示す。なお、機上の GPS センサはデー夕出力端子がないため、GPS$303 \mathrm{PT}$ と同様に信号を RS-232C で取り出せるよ うに改造した。 RS-232C の出力をパソコン ( PC98 シリーズ)に取り込みオフラインで処理した。

地上と機上の GPS データのうち、測位時刻と 使用衛星の組合せとが共に一致したデータのみを DGPS データとして採用した。オフラインで DGPS に相当する処理を行った。図 4 にデー夕処 理の手順を示す。

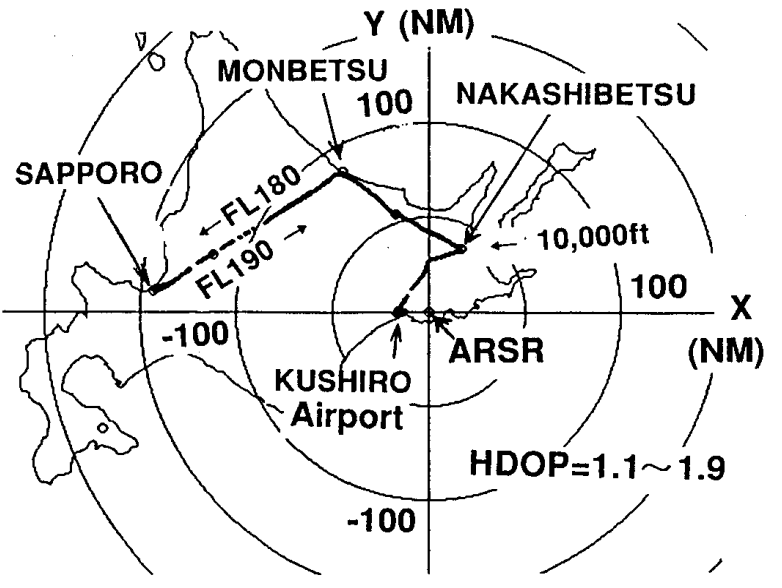

図 3 B99 による飛行コースと航跡例

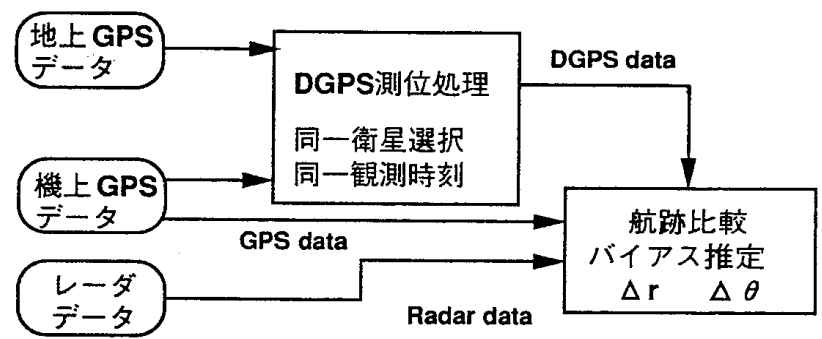

図 4 データの処理手順

表 2 GPS センサの仕様

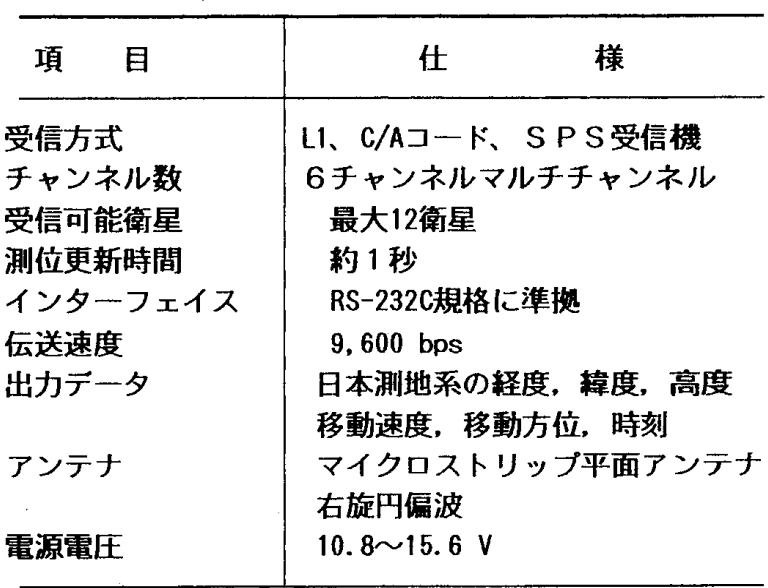




\section{3 使用データ}

航空機の航跡を比較するため下記のデー夕を用いた。

(1) 地上 GPS ( 釧路空港管制塔の屋上に設置) データ

測位時刻 $t_{g}$, 緯度 $\Phi_{g}$, 経度 $\Psi_{g}$, 高度 $h_{g}$, 使用衛星, HDOP

(2) 機上 GPS データ

測位時刻 $t_{a}$, 緯度 $\Phi_{a}$, 経度 $\Psi_{a}$, 高度 $h_{a}$, 使用衛星, HDOP

ここで、緯度, 経度はWGS-84 系から日本測地系に変換されて出力される。

(3) レーダ (釧路 ARSR) データ

図 1 の CGMT に記録した釧路 ARSR (PSR/SSR)のデータのうち次の情報を使用した。

時刻 $T^{\prime}$, 距離 $r$, 角度 $\theta$, 気圧高度 $h(\mathrm{SSR} モ-ト ゙ \mathrm{C}$ )

なお、時刻 $T^{\prime}$ は観測時刻ではなく、データの転送時刻である。このため、アンテナ回転周期 (9.71 秒) と 方位角とから推定した観測時刻 $\tau$ を用いた。

\subsection{DGPS 処理}

DGPS を実現するには幾つかの方式がある。このうち疑似距離等の補正值を利用する方式がよく使用さ れている。しかし、著者らは、ソフトウェアを改修せずに容易に実現できることから、位置の補正值を利 用する方式を採用した。

地上 GPS と機上 GPS のデータで、使用衛星の組合せと測位時刻が共に同一であるデータだけを使用し、 次式の緯度 $\Phi_{d}$, 経度 $\Psi_{d}$ を DGPS による測位值とした。

$$
\begin{aligned}
& \Phi_{d}=\Phi_{a}-\left(\Phi_{g}-\Phi_{g}{ }^{\circ}\right) \\
& \Psi_{d}=\Psi_{a}-\left(\Psi_{g}-\Psi_{g}{ }^{\circ}\right)
\end{aligned}
$$

ただし、 $\Phi_{g}{ }^{\circ}, \Psi_{g}{ }^{\circ}$ はそれぞれ地上 GPS のアンテナの設置位置の緯度, 経度である。

アンテナは釧路空港の管制塔の屋上に設置した。縮尺 $1 / 5,000$ の地図から読み取った座標は、 $\Phi_{g}{ }^{\circ}$ が $\mathrm{N}$ $43^{\circ} 2^{\prime} 27.60 ” \pm 0.06^{\prime \prime} 、 \Psi_{\mathrm{g}}{ }^{\circ}$ が $\mathrm{E} 144^{\circ} 11^{\prime} 58.39 ” \pm 0.09 ”$ である。なお、アンテナ高は約 $115 \mathrm{~m}$ である。読み 取り誤差は $0.4 \mathrm{~mm}$ 程度で、距離にして $2 \mathrm{~m}$ 程度である。

\section{5 レーダ座標系の変換}

図 5 はレーダによる測位の幾何学的関係である。 地球の形状を球で近似し、次式によりレーダ情報を 緯度 $l_{p}$, 経度 $L_{p}$ に変換した。

$$
\begin{aligned}
& l_{p}=\sin ^{-1}\left(\cos \delta \sin l_{o}+\sin \delta \cos l_{o} \cos \theta\right) \\
& L_{p}=L_{o}+\sin ^{-1}\left(\sin \delta \sin \theta / \cos l_{p}\right)
\end{aligned}
$$
ただし

$$
\delta=\cos ^{-1}\left\{\frac{\left(R+h_{o}\right)^{2}+(R+h)^{2}-r^{2}}{2\left(R+h_{o}\right)(R+h)}\right\}
$$

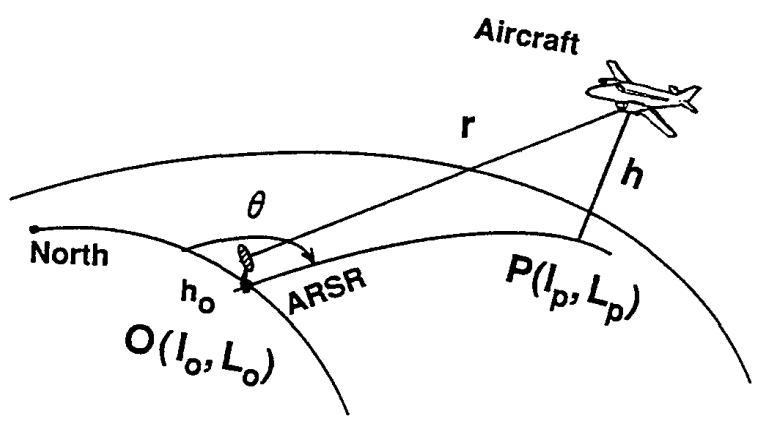

であり、 $l_{o}, L_{o}, h_{o}$ はアンテナ位置の緯度, 経度, 高度である。 $R$ は地球の半径 $(=6,371 \mathrm{~km})$ である。

図 5 レーダによる測位の幾何学的関係

\section{4. 解析方法}

\section{1 航跡の比較}

ここでは、高度を考虑しない平面座標系を考え、測角系と測距系のバイアス、 $\Delta \theta$ と $\Delta r$ とを考察する。 バイアスがあるとレーダによる観測航跡と GPS による航跡とは合致しないが、 $r, \theta$ にバイアスに相当す

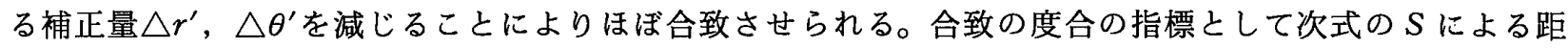
離 2 乗和を考える。

$$
S=\sum_{i=1}^{N r}\left|P_{r i}\left(\triangle r^{\prime}, \triangle \theta^{\prime}\right)-P_{g}\left(t_{i}\right)\right|^{2}
$$

これを最小化する $\Delta r^{\prime}, \triangle \theta^{\prime}$ を求め、バイアスを見積もる。但し、 $P_{r i}\left(\triangle r^{\prime}, \triangle \theta^{\prime}\right)$ は観測時刻 $t=t_{i}$ のと きのレーダによる観測位置である。 $P_{8}(t)$ は時刻 $t$ における真の位置の推定值で、これは時刻 $t$ 近傍の 
GPS データを平滑化して求める。 $N_{r}$ は使用レーダデータ数である。

4.2 GPS データの平滑化

航空機の航跡の平滑化には、約 1 秒毎に得られるDGPS または GPS データの観湘時刻 $t_{i}$, 緯度 $\Phi_{i}$, 経 度 $\Psi_{i},(i=1,2, \ldots, N)$ を用いる。まず、基準点 $Q$ (緯度 $\Phi_{q}$, 経度 $\left.\Psi_{q}\right)$ を原点とした $X, Y$ 座標に次 式(6) で変換する。

$$
\begin{array}{ll}
x_{i}=d_{i} & \cos \alpha_{i} \\
y_{i}=d_{i} & \sin \alpha_{i}
\end{array}
$$

ただし

$$
\begin{aligned}
& d_{i}=R \tan ^{-1}\left\{\left(A_{1}^{2}+A_{3}{ }^{2}\right)^{1 / 2} / A_{2}\right\} \\
& \alpha_{i}=\tan ^{-1}\left(A_{1} / A_{3}\right)
\end{aligned}
$$

ここで

$$
\begin{aligned}
& A_{1}=\cos \Phi_{i} \sin \left(\Psi_{i}-\Psi_{q}\right) \\
& A_{2}=\sin \Phi_{i} \sin \Phi_{q}+\cos \Phi_{i} \cos \Phi_{q} \cos \left(\Psi_{i}-\Psi_{q}\right) \\
& A_{3}=\sin \Phi_{i} \cos \Phi_{q}-\cos \Phi_{i} \sin \Phi_{q} \cos \left(\Psi_{i}-\Psi_{q}\right)
\end{aligned}
$$

である。

こうして作成した位置データを用いて最小 2 乗法により次のモデルの係数を決める。

$$
\begin{aligned}
& X(t)=C_{1}\left(t-t_{i}\right)^{2}+C_{2}\left(t-t_{i}\right)+C_{3} \\
& Y(t)=C_{4}\left(t-t_{i}\right)^{2}+C_{5}\left(t-t_{i}\right)+C_{6} \\
& \text { for } t_{i}-\left(t_{i}-t_{i-1}\right) / 2 \leqq t<t_{i}+\left(t_{i+1}-t_{i}\right) / 2
\end{aligned}
$$

ここで、 $C_{j}(j=1,2, \ldots, 6)$ は時刻 $t_{i}$ の前後の $k$ 個のデータ (総数 $2 k+1$ 個) を用いて求めた最小 2 乗 推定量である。これは $X$ 方向および $Y$ 方向の運動を等加速度運動と仮定している。これにより、 $t=t_{j}$ に おける真の位置の推定值を $P_{\mathrm{g}}\left(t_{j}\right)=P_{\mathrm{g}}\left(X\left(t_{j}\right), Y\left(t_{j}\right)\right)$ で表す。

4.3 GPS の航跡とレーダの航跡の距離

いま、(7)，(8) 式により、(3)，(4) 式で求めたレーダによる航跡を基準点 Q 換して得た值を $\left(\xi_{j}, \eta_{j}\right)$ とする。レーダにおける観測時刻を $\tau_{j}(j=1,2, \ldots, N r)$ とする。GPS の時刻 $t$ とレーダの時刻 $\tau$ が $\triangle T$ だけずれているとして

$$
\tau=t+\triangle T
$$

とする。このとき、レーダによる観測位置と真の位置の推定值との 2 次元距離を $\varepsilon_{j}$ とて、この 2 乗和

$$
\begin{aligned}
S & =\sum_{j=1}^{N r} \varepsilon_{j}{ }^{2} \\
& =\sum_{j=1}^{N r}\left\{\left(\xi_{j}-X\left(\tau_{j}-\triangle T\right)\right)^{2}+\left(\eta_{j}-Y\left(\tau_{j}-\triangle T\right)\right)^{2}\right\}
\end{aligned}
$$

を合致の良さの評価量とした。図 6 に航跡の関係 図を示す。

測定值 $\xi_{j}, \eta_{j}$ はレーダの測定系のバイアス誤 差 $\triangle r, \triangle \theta$ の関数で、 $\tau_{j}$ は時刻のずれ $\triangle T$ の関 数である。よって、観測值 $(r, \theta, \tau)$ から補正值 $\left(\triangle r^{\prime}, \triangle \theta^{\prime}, \triangle T^{\prime}\right)$ を引いたすのを用いて (17) 式 の $S$ を計算し、これを最小とする補正值を求め ることによりバイアス誤差を推定できる。

\section{5. 解析結果}

\section{1 固定点での測位結果}

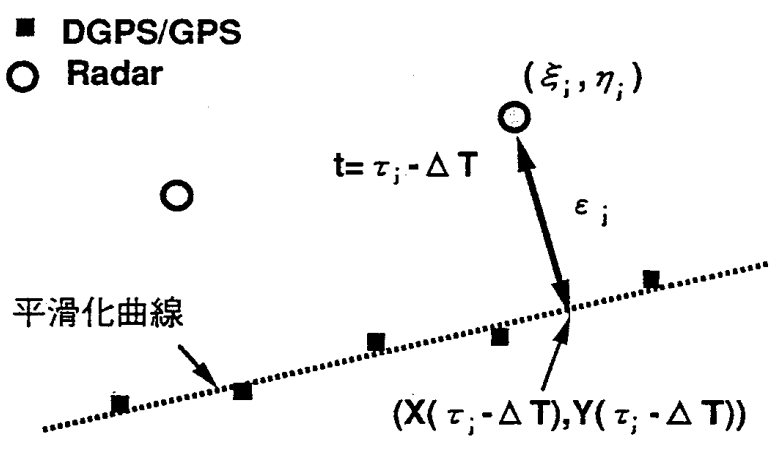

図 6 航跡の合致の度合を評価するための距離

図 7 は釧路空港における GPS 単独測位の結果である。観测期間は飛行実験期間中の約 2 時間半である。 表 3 にその統計值を示す。文献 [7] [8] 等で指摘されているように、SAの変動はランダムではない。 SA の影響と思われるが、観測分布は必ずしも対称とはならず平均值すゼロにはなっていない。なお、 
HDOP は $1.1 \sim 1.9$ で、2drms 值は $69.2 \mathrm{~m}$ であった。

図 8 は飛行実験を終えた航空機が空港内を走行し駐機位置に停止するまでの航跡を比較したあのである。 航空機の停止後の期間は 10 秒ほどである。GPS 単独、DGPS の場合と固定点での観測值を示した。 DGPS では SA 等による誤差が相殺されて真の駐機位置に $5 \mathrm{~m}$ 程度の誤差で一致していることがわかる。

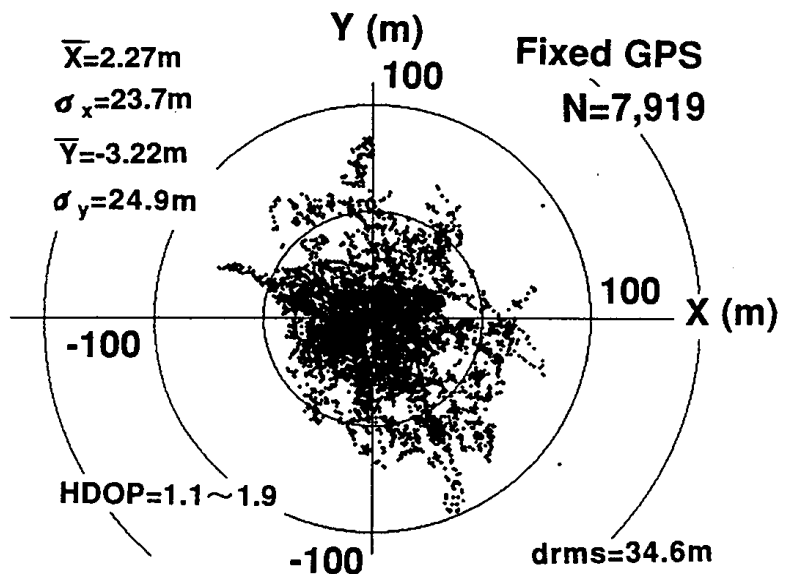

図 7 固定地点 (釧路空港) による観測結果

\section{2 レーダの航跡との比較}

図 9 は実験機の離陸から着陸までの航跡である。 地上 GPS 近傍に駐機していた実験機は上から 2 番 目の誘導路を通り、滑走路を針路約 $160^{\circ}$ (右下) で 離陸し右旋回の後、地上 GPS 上空を通過し中標津 に向かった。帰路は約 $340^{\circ}$ (左上) の方向から着陸 し、上から 3 番目の誘導路を通り駐機位置に戻った。 図 9 ではGPS 単独, DGPS, レーダの航跡を併せ てプロットした。レーダは離陸時のみで DGPS データは一部しかとれていない。GPS 単独の航跡 では、SA 等の誤差により、実験機が誘導路からは み出ている部分が見られる。また、レーダのプロッ 卜は GPSのそれと $0.2 \mathrm{NM}$ 前後ずれていることが わかる。レーダサイトから約 $20 \mathrm{NM}$ と近距離なの で、測距系のバイアスの影響が大きいと推測される。

\section{3 バイアス誤差の推定}

図 3 の航跡のうちバイアスの推定に利用した航跡 の部分を図 10 に示す。観測時間は 11 時 32 分から 11 時 45 分までの 13 分間である。この部分のデー 夕を利用したのはDGPSのデータがほほ連続的に 取得できているためと、紋別で針路が変わるためで ある。すなわち、札幌 $\rightarrow$ 紋別の部分では測距誤差の 影響が大きく紋別 $\rightarrow$ 中標津の部分では測角誤差の影 響が現れ易いため、双方のバイアスを検出するのに 都合がよい。

DGPS とGPS 単独の双方の場合について、紋別ビーコン (NDB) 基準点にとり $X, Y$ 座標に变換し、 バイアスの推定の計算を行った。平滑化では $k=10$ とし隣接した 21 個のデー夕を用い、各点における係 数を計算した。なお、(14)，(15) 式で $t$ と $t_{i}$ が 3 秒以上離れている場合にはデータとして使用しないことに

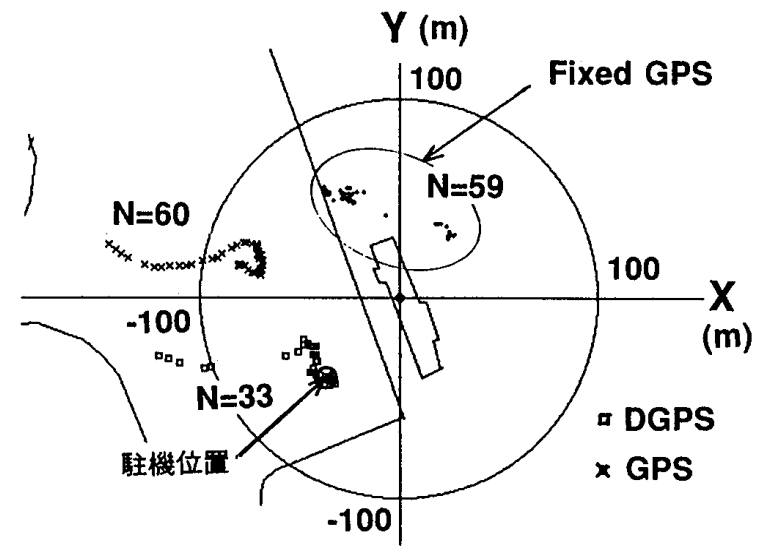

図 8 DGPS による航跡の比較例 (○印が駐機位置)

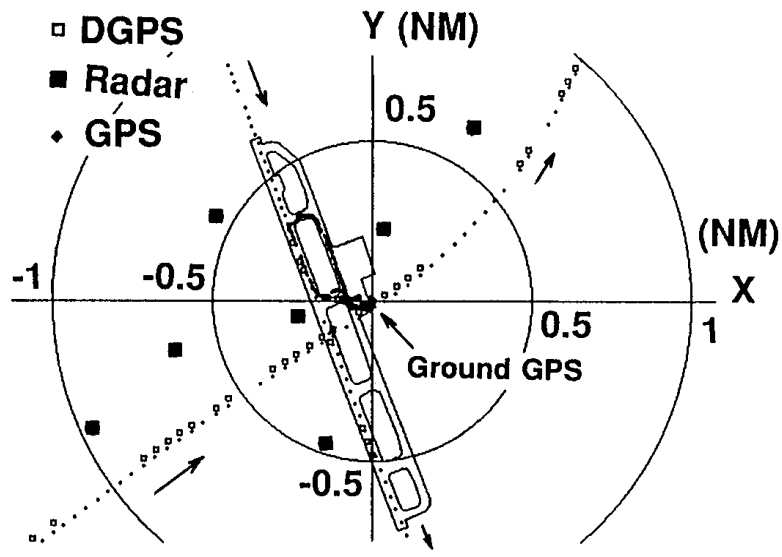

図 9 釧路空港近傍における航跡の比較例

表 3 釧路空港における定点測位結果

ただし $D=\left(X^{2}+Y^{2}\right)^{1 / 2}, \operatorname{drms}=\left[\sum_{i=1}^{N} D_{i}{ }^{2} / N\right]^{1 / 2}=34.6 \mathrm{~m}$

\begin{tabular}{|c|c|c|c|c|c|c|c|}
\hline 方向 & $\begin{array}{c}\text { 平均 } \\
\text { (m) }\end{array}$ & $\begin{array}{l}\text { 標準佰差 } \\
(\mathrm{m})\end{array}$ & $\begin{array}{l}\text { 曼大 } \\
(m)\end{array}$ & $\begin{array}{l}\text { 最小 } \\
\text { (m) }\end{array}$ & 奀度 & 尖唐 & $\begin{array}{c}\text { 摽本数 } \\
N\end{array}$ \\
\hline$x$ & 2. 27 & 23. 7 & 85.8 & -70.1 & 0.30 & 2.91 & 7,919 \\
\hline$Y$ & -3.22 & 24. 9 & 84.5 & -90.3 & 0.05 & 3. 98 & 7,919 \\
\hline D & 29.6 & 17.8 & 109.2 & 0.58 & 0.88 & 3. 33 & 7,919 \\
\hline
\end{tabular}


した。

表 4 に $S$ を最小化する補正値の計算結果を示す。補正值は $\triangle T^{\prime}, \triangle r^{\prime}, \triangle \theta^{\prime}$ をそれぞれ 0.1 秒, 0.01 $\mathrm{NM}, 0.001^{\circ}$ 毎に変化させ数值計算で最小值を捜した。バイアスの值は DGPS では $\triangle r=0.15 \mathrm{NM}, \triangle \theta=$ $0.082^{\circ} 、 \mathrm{GPS}$ 単独では $\triangle r=0.16 \mathrm{NM}, \triangle \theta=0.084^{\circ}$ で、双方とも同程度の值である。これらの值が僅かに 異なるのは、GPS 単独のデータに含まれる誤差の影響と思われる。

距離系に関しては、SSR トランスポンダの応答遅延を考慮する必要がある。これは $00.5 \mu \mathrm{s}(0.08 \mathrm{NM})$ の差異が許容されている。このため、真の距離系のバイアスは実験機のトランスポンダの応答遅延の值を 差し引いた值となる。この値は未知なので、真の距離系のバイアスは

$$
0.07 \mathrm{NM}<\triangle r<0.23 \mathrm{NM}
$$

程度と考えるべきであろう。いずれにしてあ、大体 LSB 程度であり、航空管制で使用する場合は問題に ならない程度の大きさである。

図 11 に紋別 NDB 付近の DGPS の航跡とレーダの航跡を示す。図 12 はバイアスを補正後の紋別付近の 航跡を示す。図 13 ではバイアス補正前と補正後の釧路空港近傍の航跡を比較する。図 14 は札幌 DME 近 傍の航跡の比較結果である。これらから、バイアスを補正した後のレーダの航跡が DGPSまたはGPSの それとょく合致することがわかる。釧路 ARSR から航空機までの距離は20NM から $140 \mathrm{NM}$ と異なるが、 いずれの場合む、バイアスがよく補正されていることを確認できた。

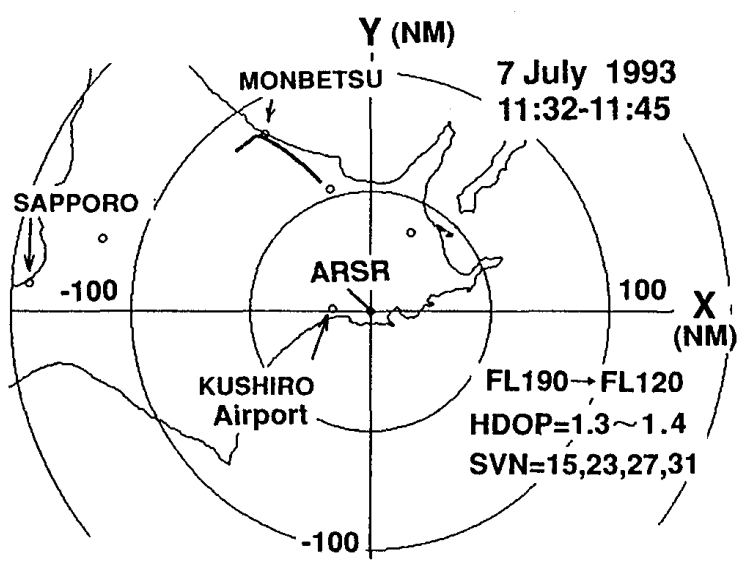

図 10 較正のための解析に使用したデータ 取得区間

表 4 S を最小化する補正值

\begin{tabular}{|c|c|c|}
\hline 項 & DGPS & GPS単独 \\
\hline 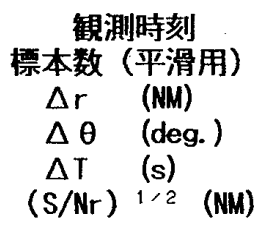 & $\begin{array}{c}11: 32 \sim 11: 45 \\
347 \\
0.15 \\
0.082 \\
18.5 \\
0.137\end{array}$ & $\begin{array}{c}11: 32 \sim 11: 45 \\
524 \\
0.16 \\
0.084 \\
18.2 \\
0.153\end{array}$ \\
\hline $\begin{array}{l}\text { レータ標本数 } \mathrm{Nr} \\
\text { レータ倠測時刻 }\end{array}$ & $\stackrel{65}{11: 33 \sim 11: 44}$ & $\stackrel{66}{11: 33 \sim 11: 44}$ \\
\hline
\end{tabular}

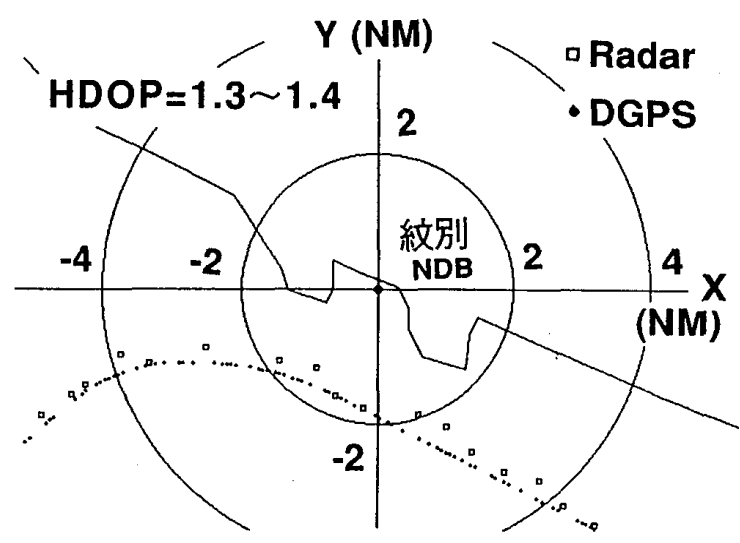

図 11 紋別近傍における航跡(補正なし)

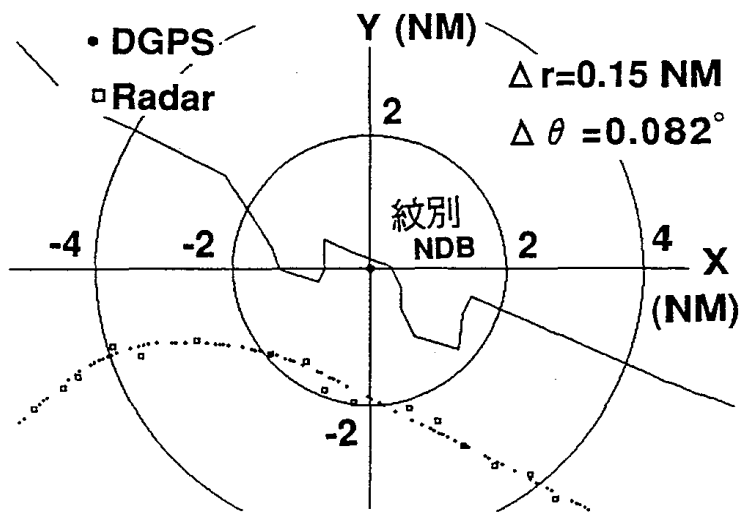

図 12 紋別近傍における航跡(バイアス補正後) 


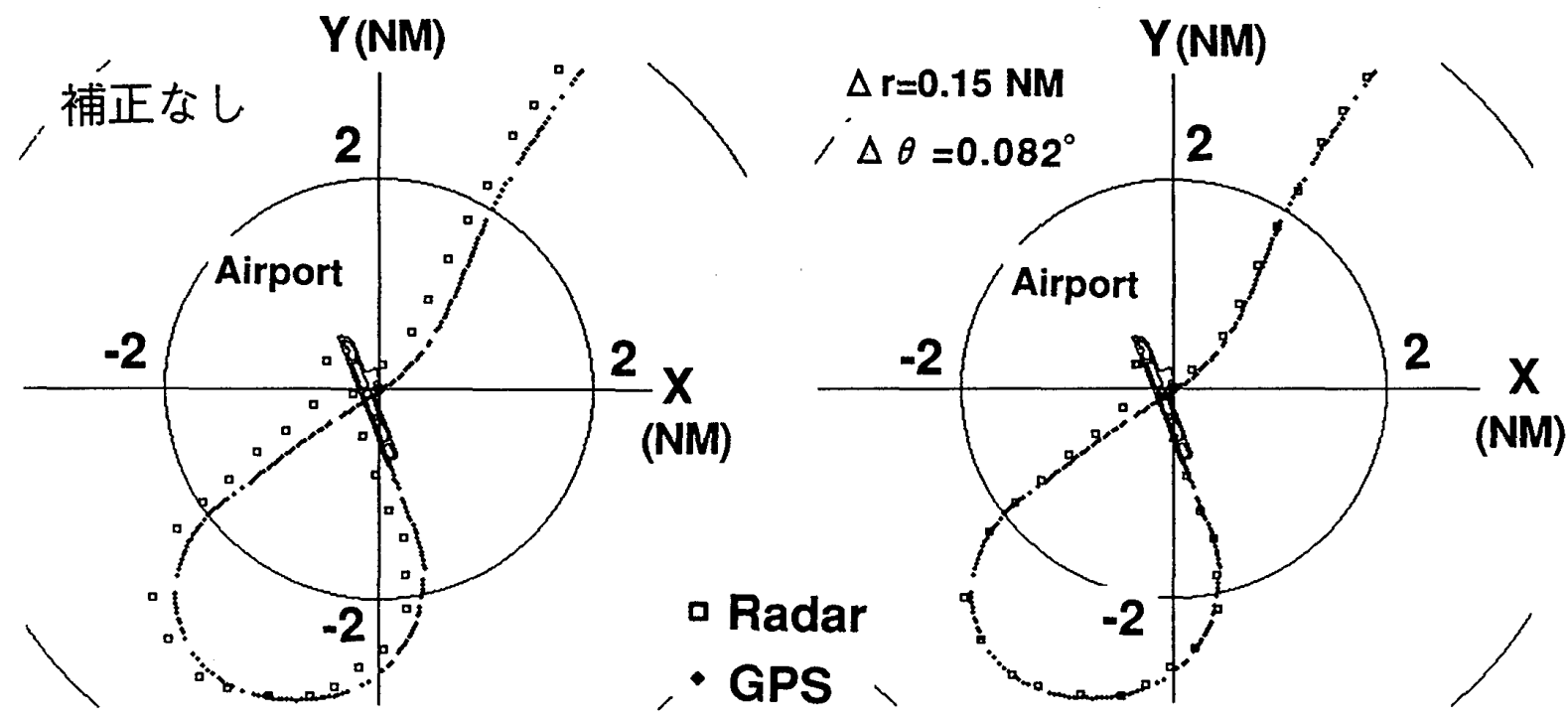

図 13 釧路空港近傍におけるバイアス補正前後の航跡の比較
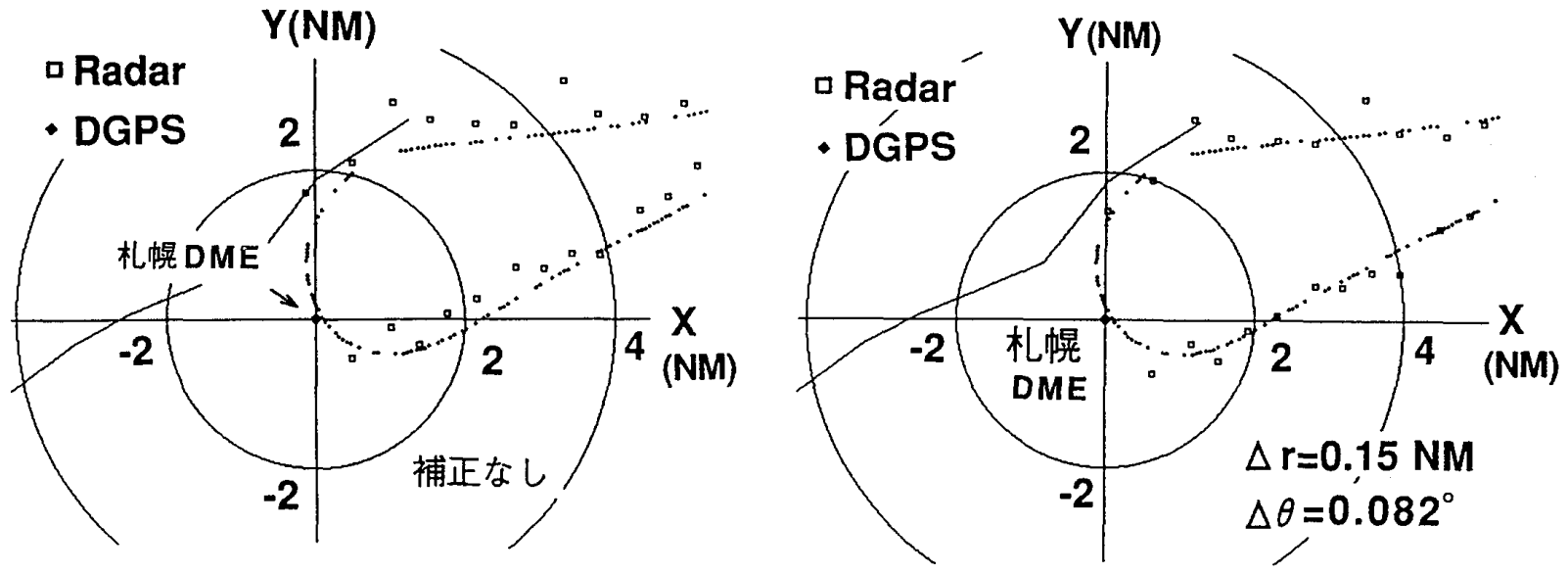

図 14 札幌近傍におけるバイアス補正前後の航跡の比較

\section{6. 考 察}

\subsection{GPS の誤差の影響}

GPS 単独測位では $100 \mathrm{~m}(2 \mathrm{drms})$ 程度の測位誤差が有り得る。本実験では、この誤差を軽減するため DGPS 処理を試みたが、2つの受信機間の距離が最大で $140 \mathrm{NM}$ 程度になる。近距離では図 8 で示したよ うに数 $\mathrm{m}$ 程度の精度が期待できると思われるが、この場合の精度は確認できなかった。

最小 2 乗法による航跡の平滑化ではデー夕取得期間に比べて周期の短い変動成分は除去できるが周期の 長い変動成分は除去できない。従って SA の周期の長い変動分はバイアス推定の誤差として働く。

いま、最悪の場合として $100 \mathrm{~m}$ の誤差を想定すると、この值は距離系で $0.054 \mathrm{NM}$ に相当する。角度系 では、距離が $100 \mathrm{NM}$ で $0.03^{\circ} 、 20 \mathrm{NM}$ で $0.15^{\circ}$ である。

バイアスを推定する際の精度は、バイアスの值よりも一桁程度小さいことが望ましい。LSB (距離系 $0.125 \mathrm{NM}$, 角度系 $\left.0.088^{\circ}\right)$ にくらべ大きなバイアスを推定する場合は DGPS でも GPS 単独であ大差ない と思われる。しかし、LSB 程度のバイアスを問題にする際は、GPS 単独による精度は必ずしあ十分では ない。他方、DGPS で誤差を $20 \mathrm{~m}$ 程度に抑えれば、距離系が $0.011 \mathrm{NM}$ 、角度系で距離が $100 \mathrm{NM}$ $0.006^{\circ} 、 20 \mathrm{NM}$ で $0.03^{\circ}$ と、近距離を除いて誤差は殆ど問題にならない。 


\section{2 本方法の特徵}

本方法の特徵と注意事項をまとめると次のとおりである。

1）(17) 式による推定精度は、平滑化する航跡データの精度に依存する。最小 2 乗法は平均が 0 でない変動 に対してはあまり有効でないため、このデータにはバイアス誤差がなくランダム成分のみであることが 望ましい。

2）バイアスを評価するレーダデータについてあ同様である。レーダ信号の欠落等により局所的なバイア スが現れる空域での実験データは使用しないような配慮が必要である。

3）本方法は飛行した全ての航跡について一貫した方法で評価ができる利点があるが、3つの未知パラ メータがあり、航跡デー夕数が増えると計算時間が問題になってくる。

4) 飛行実験の際はレーダサイトとの幾何学的関係を考虑してバイアス誤差を検出しやすいコースを計画 することが肝要である。

\section{7. むすび}

航空路監視レーダの測定系を較正するために行った、GPS を利用した飛行実験について報告した。本 稿で示したことをまとめると次のようになる。

i) 航空機の航跡をDGPS/GPS とレーダで観測し、双方による航跡が合致するように測定系のバイアス を補正する解析方法を提案した。

ii）オフライン DGPS 処理を行った実験データを解析し、上記方法によるバイアス誤差の補正例を示し、 その有効性を確かめた。

本方法の推定精度は真の航跡の推定精度に依存するため、できる限り SAのかかった GPS 単独測位で はなくDGPS 测位によるデータを用いることが望ましい。

今後の課題としては、本方法による推定精度の検討やバイアス推定アルゴリズムの改良などがある。

\section{[謝 辞 $]$}

GPS 信号を取り出せるように実験装置を改造して下さった電子航法研究所の惟村和宣博士に謝意を表 します。また、実験にご協力いただいた運輸省釧路空港事務所の関係各位、実験関連装置を貸与下さった 当所設置技術研究室の各位に感謝致します。

\section{参 考 文 献}

(1) 天井, 長岡：”洋上航空路における横方向経路逸脱量の解析”, 日本航海学会論文集， $86 ，$ p. $75-83$, 1991

（2）日本測地学会編：「新訂版 GPS一人工衛星による精密測位システムー」，日本測量協会，1989

(3) Aeronautical Telecommunications Part 1: ICAO Annex 10 to the Convention on Int'1 Civil Aviation, Vol.1, 1985

（4）村田正秋：“GPS の高度利用”, 計測自動制御学会, 第 8 回誘導制御基礎講習会テキスト, p.1-20, 1993 年 5 月

（5）石川，小野，村田："DGPS の飛行実験”，日本機械学会第 1 回交通物流部門大会講演論文集，p.306 $-359,1992$ 年 11 月

（6）長岡 栄：”球面三角法によるルート設計のための計算法”，航空管制，p. $28-34,1978$ 年 7 月号

（7）村田, 張替："GPSにおけるセレクティブ・アベィラビリティ(選択利用性) の観測と評価解析”, 航 空宇宙技術研究所報告, NAL TR-1105, 1991 年 4 月

(8) 片山 晋："GPS の選択利用性 (SA) の観察”, 日本航海学会誌, 113 号, p.4-11, 1992 


\section{質 疑 応 答}

西 周次 (株カナデン)：レーダの覆域内で固定誤差が一定でないように思いますが、場所による誤差の差 はありませんか。また、固定誤差の経年変化のような長時間の変化はありませんか。

長岡 栄：場所による変化としてはマルチパスなどによるすのが考えられます。この影響は通常局所的に 現れますので、誤差の傾向をみていれば区別できると思います。経年変化によるものああるかす知れま せん。

新井康夫 (海技大学校)：レーダの距離, 方位において生じるバイアスの要因を教えて下さい。

長岡 栄: 距離系, 角度系とあに設定時の設定誤差があります。デジタル信号処理をしており、最小量子 化単位程度の設定誤差は許容されています。また角度系では応答信号の欠落により、特定の空域で局所 的なバイアス誤差となる場合などがあります。 